\title{
sciendo
}

DOI 10.2478/sbe-2021-0014

SBE no. 16(1) 2021

\section{MEASURING PERFORMANCE IN THE LUXURY INDUSTRY: IS THERE A DIFFERENCE IN PERFORMANCE BETWEEN THE TOP AND BOTTOM PLAYERS IN THE INDUSTRY?}

\author{
ȘERBAN RADU-ALEXANDRU \\ Lucian Blaga University of Sibiu, Romania
}

\begin{abstract}
:
This paper presents a methodology that consists of a Z-score function applied on a set of indicators for the luxury industry and then standardized to obtain a ranking of the companies on a scale between 10 and 100. To measure the performance for the top 5 - LVMH, Estee Lauder, Richemont, Kering, Essilor Luxottica, and bottom 5 - Aeffe, Tribhovandas, Van de Velde, Mulberry, Trinity companies (based on Deloitte global ranking in 2019) in the luxury industry and to unveil which are the performance drivers. By applying this methodology it can be made a comparison in performance between the top and the bottom companies in the luxury industry. The performance score is calculated for ten years $(2010$ - 2019) on public companies from the luxury industry.
\end{abstract}

Key words: Luxury industry, Performance, Z-score, Ratio Analysis

\section{Introduction}

In the Z-score function, originally developed by the finance professor Edward Altman, ratios were selected and calculated based on the financial statements of the companies from the luxury industry. Based on the ratios analysis, which is a method, a quantitative one for capturing the overall perspective over a company's' financial standing, were selected ratios that unveil how the companies perform over a period of time. All the ratios are important for a company because help us to evaluate its financial health and stability, providing crucial information for managers, investors, analysts, shareholders, etc. However, there are authors (Brigham, E. F., \& Houston, J. F., 2019) who claim that some ratios are more important than others e.g. ROA (Return on Assets) and ROE (Return on Equity), considered also fundamental ratios. Also, to provide consistency to the ratio analysis, because each ratio measures different aspects from the company's' financial statement, authors put these ratios in categories (Brigham, E. F., \& Houston, J. F., 2019; Bloomenthal A., 2020). We can find ratios divided into 4, 5, or 6 categories, depending on the research. Generally, all these classifications are covering ratios that measure liquidity and/or solvency, debt and assets management, profitability, and market value. Another difference consists in which ratios are selected for each category. 
In this paper, the ratio analysis is divided into 6 categories that measure for the 10 companies ( 5 from top and 5 from bottom ranking) in the luxury industry: liquidity, solvency, assets management, debt management, profitability, and market value, see Figure

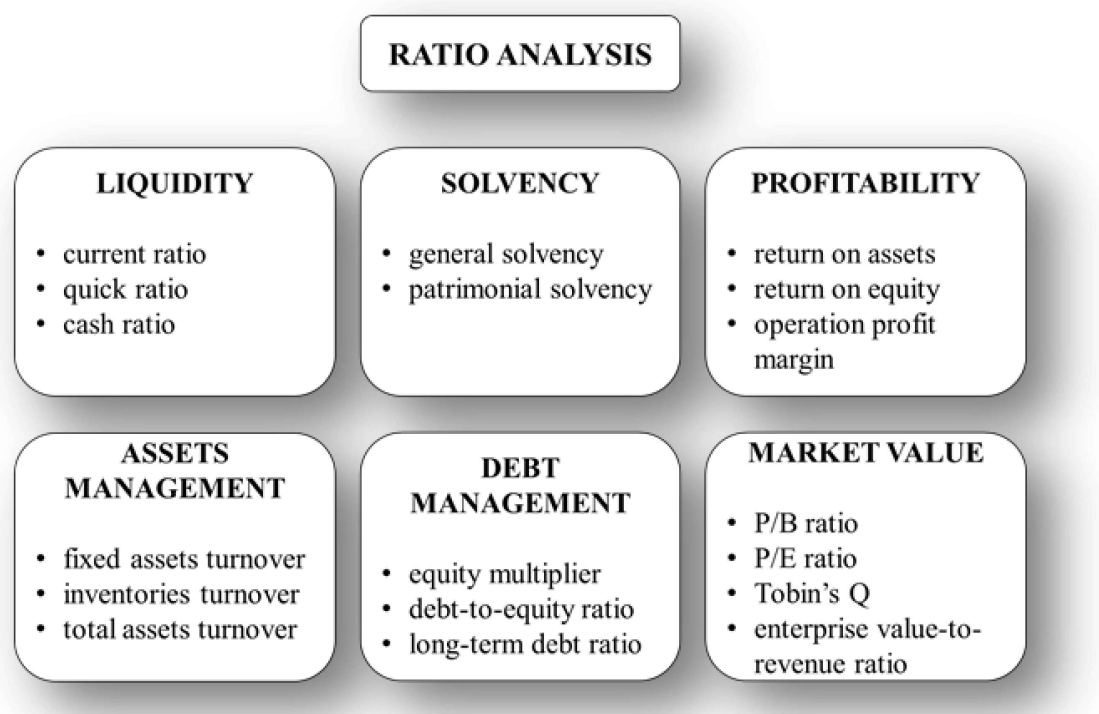

Fig. 1. Representations of the ratios selected in the analysis

To obtain the Z-score function with the ratios that accurately describe the performance for the companies analyzed, only those ratios that have the highest importance coefficient were taken into account, by optimizing each ratio. Then, the Zscore function that results was applied to each company, and based on the range, minimum and maximum values of the ratios analyzed in the sample and by using the transformation formula. Since financial leverage and the degree of long-term indebtedness cannot be optimized, we cannot conclude that a high or low level of indebtedness is optimal for increased performance, as a result, the 2 ratios were used for adjustment. Using the sector average as an attractor, the two variables mentioned before were adjusted by $+/$ - the values recorded below or above the sector average. The results obtained by applying the Z-score function for each company in the analyzed period (2010 - 2019), were normalized to obtain the lowest and highest scores between 10 - as the weakest result and respectively 100 - the best result recorded by the company (described in the methodology, Serban R., 2020).

That being said, the article is further structured as follows: in the Industry overview, Section 2, presents the currents state of the industry and the trends; research Methodology is described in the third part; the empiric findings and discussions are described in the fourth section of the paper; the Conclusions of the study are outlined in the final part of the article. 


\section{Industry overview}

The luxury industry shows a high growth potential not only from the leading and well known and established companies in the industry like LVMH, Kering, Richemont but also from new entrants in the industry such as Chanel Limited. The industry also records double digits growth rate YoY in terms of revenue, see Figures 2 and 3. Even though there are signs of economic slowdown, the luxury industry is not following this trend, furthermore, the appetite for luxury goods, especially in China, fuels the growth potential for these companies. Also, focusing on a new type of consumers and adapting their brand strategies in this direction, play an important role in the success of the luxury industry despite the current economic context.

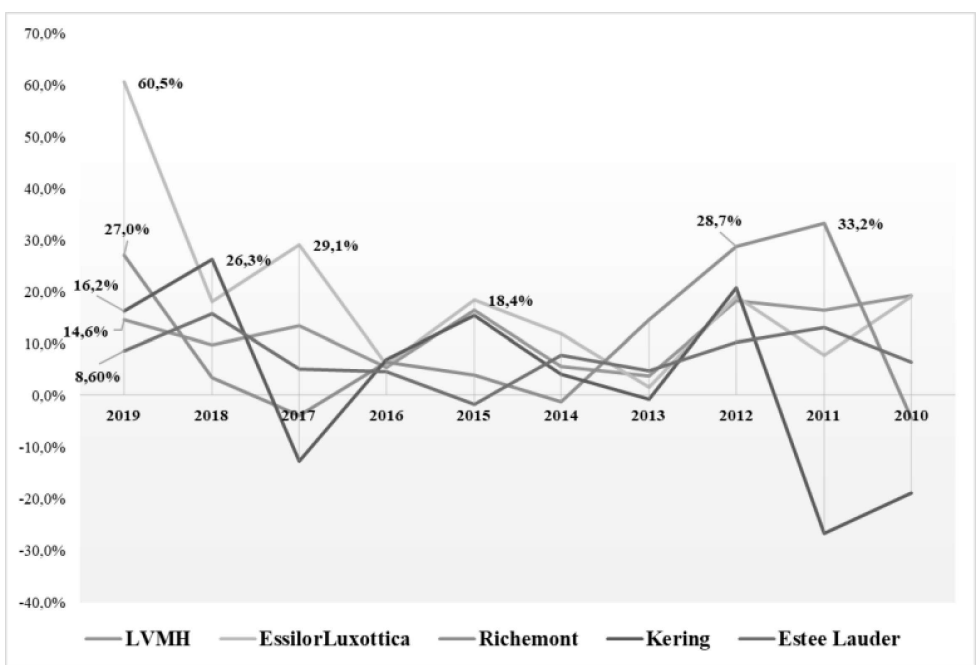

Fig. 2. Annual YoY Revenue growth rate, top $\mathbf{5}$ companies in luxury industry, 2010-2019

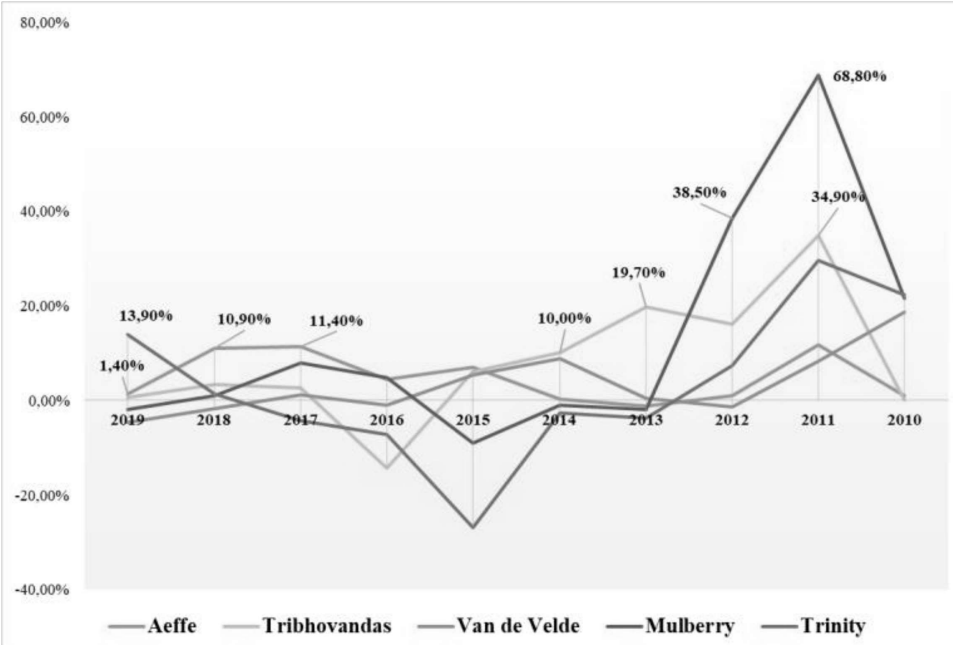

Fig. 3. Annual YoY Revenue growth rate, bottom 5 companies in luxury industry, 2010-2019 
For the major players (LVMH, Estee Lauder, Richemont, Kering, Essilor Luxottica) in the luxury industry, the YoY growth rate in terms of revenue in the period analyzed recorded double digits, on average of $10,5 \%$, compared with the other companies, in this case, the bottom-ranked companies (Aeffe, Tribhovandas, Van de Velde, Mulberry, Trinity) which recorded an average YoY growth rate in term of revenue of only $6,49 \%$. Also, if we compare the revenues for the period analyzed, the difference it's huge, see Table 1, in favor of the large companies. This is the main reason why this paper measures the performance of these companies by using a score to be able to compare them at an even ground.

Table 1. Total revenues, companies in the luxury industry, period 2010-2019, mil. \$

\begin{tabular}{|c|c|c|c|c|c|c|c|c|c|c|c|}
\hline 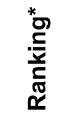 & 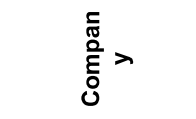 & 2019 & 2018 & 2017 & 2016 & 2015 & 2014 & 2013 & 2012 & 2011 & 2010 \\
\hline 1 & LVMH & 60,06 & 55,23 & 48,08 & 41,59 & 39,56 & 40,63 & 38,53 & 35,95 & 32,90 & 26,91 \\
\hline 2 & Estee Lauder & 14,86 & 13,68 & 11,82 & 11,26 & 10,78 & 10,97 & 10,18 & 9,71 & 8,81 & 7,80 \\
\hline 3 & Richemont & 16,19 & 12,87 & 11,67 & 12,23 & 13,12 & 13,43 & 13,06 & 12,20 & 9,10 & 7,31 \\
\hline 4 & Kering & 17,78 & 16,12 & 12,20 & 13,70 & 12,85 & 13,31 & 12,82 & 12,51 & 11,21 & 14,58 \\
\hline 5 & EssilorLuxottica & 19,46 & 12,78 & 10,36 & 7,87 & 7,45 & 7,52 & 6,73 & 6,41 & 5,83 & 5,15 \\
\hline 82 & Aeffe & 0,39 & 0,41 & 0,35 & 0,31 & 0,30 & 0,33 & 0,33 & 0,33 & 0,35 & 0,30 \\
\hline 87 & Tribhovandas & 0,25 & 0,27 & 0,25 & 0,25 & 0,32 & 0,30 & 0,31 & 0,29 & 0,26 & 0,19 \\
\hline 94 & Van de Velde & 0,22 & 0,24 & 0,24 & 0,23 & 0,23 & 0,26 & 0,24 & 0,23 & 0,26 & 0,23 \\
\hline 98 & Mulberry & 0,22 & 0,22 & 0,22 & 0,23 & 0,24 & 0,26 & 0,26 & 0,27 & 0,19 & 0,11 \\
\hline $\begin{array}{l}10 \\
0 \\
\end{array}$ & Trinity & 0,25 & 0,22 & 0,22 & 0,23 & 0,25 & 0,34 & 0,35 & 0,36 & 0,34 & 0,26 \\
\hline
\end{tabular}

${ }^{*}$ Ranking is provided by Deloitte in their report Global Powers of Luxury Goods 2019. Bottom 5 companies were selected according to the criteria of listing on the stock exchange for access to financial data.

Source: Authors computation in Excel, data from Thomson's Reuters' Eikon Refinitive platform.

\section{Research Methodology}

\section{A. Ratios analysis}

As mentioned in the Introduction, the 6 categories of ratios selected for the analysis are: liquidity, solvency, profitability, debt management, assets management, and market value ratios, and are formally described in appendix 1 (Serban R. and Herciu M., 2019).

\section{B. Z-score function}

Starting from the $Z$ or Zeta function developed by Altman, it was proposed the following Z-score function, for measuring the company's performance, so the $Z$ function will be in the form (Serban R, 2020):

$z=a_{1} x_{1}+a_{2} x_{2}+a_{3} x_{3}+\ldots+a_{n} x_{n}+\sum b$

Where:

a1 $\ldots$ an $=$ the importance coefficient of the variable $X$, calculated as optimal either by maximization or by minimization, depending on the nature of the variable $\mathrm{X}$; 
To determine the Z-score function for the companies analyzed, only those variables that have the highest importance coefficient ' $a$ ' will be taken into account.

If the variable $X$ is optimized by the maximum, then:

$$
a=\frac{1}{X_{\max }-X_{\min }} \text {, and } b=\frac{-x_{\min }}{X_{\max }-X_{\min }}
$$

If the variable $X$ is optimized by the minimum, then:

$$
a=\frac{1}{X_{\min }-X_{\max }} \text {, and } b=\frac{-x_{\max }}{X_{\min }-X_{\max }}
$$

The importance coefficient ' $a$ ' is calculated according to the above formulas for each of the variables (ratios selected).

The variables financial leverage and the long-term debt ratio, respectively, will be used as variables for adjusting the Z-score function. After determining the Z-score function, for the variables mentioned earlier the average will be calculated, and it will be used as a benchmark (stationary point) for adjustments. Tested intersubjectively, the average is a representative value, a trend. If, for example, a new company enters the market with values well below or above the industry average, in time the average will act as an attractor for that company, and companies will tend towards that long-term average.

As a result, the variables financial leverage and the long-term debt ratio are found in the Z-score function. For companies that record values of these variables above average, the adjustment will be made by minimizing, to the industry average, and if the values of variables are below average, the adjustment will be made by maximizing, to the industry average.

\section{Data normalization}

For results of the Z-score function determined described above, it was applied the following data normalization formula (Serban R, 2020):

$$
Z_{i j n o r m}=90 * \frac{Z_{i j}-Z_{i m i n}}{Z_{i \max }-Z_{i m i n}}+10
$$

Where:

Zij - represents the calculated value of the Z-score i for company j;

Zimin - represents the minimum level of the Z-score i function;

Zimax - represents the maximum level of the $Z$ score i function;

Selected normalization interval: [10; 100].

Based on the interval above, minimum and maximum values of the variables analyzed in the sample and based on the transformation formula, the lowest and highest scores of the variables analyzed for each company will be between 10 - as the weakest result and respectively 100 - the best result recorded by the company. The above formula is an adaptation of the one used by the World Economic Forum to determine the Global Competitiveness Index. 


\section{Results and discussions}

In the following, taking into account the elements described in the methodology, the ratio analysis was performed, the most important and relevant variables were selected, and the Z-score function was determined in order to calculate the performance score for LVMH (France), Estee Lauder (U.S.), Richemont (Switzerland), Kering (France), Essilor Luxottica (France-Italy), and bottom 5 - Aeffe (Italy), Tribhovandas (India), Van de Velde (Belgium), Mulberry (U.K.), Trinity (Hong Kong).

Based on the methodology, in this paper the approaches considered were:

- annual financial statements;

- the analysis period $2010-2019$;

- the data is taken from Thomson's Reuters' Eikon Refinitive platform;

- the Z-score function was used to calculate the score performance for the period analyzed, for each company considered in the research;

\section{A. Ratio analysis results}

As mentioned in Introduction and according to the methodology, the ratios were calculated for each of the 10 companies, in the period analyzed. Then, the variables with the highest importance coefficient 'a' were selected, see Table 2.

Table 2. Ratio analysis results, importance coefficients

\begin{tabular}{|c|c|c|c|c|}
\hline Variables & $\begin{array}{c}\text { a } \\
\text { Coefficient }\end{array}$ & $\begin{array}{c}\text { b } \\
\text { Coefficient }\end{array}$ & $\begin{array}{c}\text { a Coefficient } \\
\text { (Pozitive values) }\end{array}$ & $\%$ \\
\hline ROA & 3,983661 & $-0,00866$ & 3,9837 & $26,53 \%$ \\
\hline ROE & 2,490844 & $-0,01103$ & 2,4908 & $16,59 \%$ \\
\hline long-term debt ratio & $-2,0591$ & 1,022602 & 2,0591 & $13,71 \%$ \\
\hline patrimonial solvency & 2,013585 & $-1,01359$ & 2,0136 & $13,41 \%$ \\
\hline operating profit margin & 1,838978 & $-0,03835$ & 1,8390 & $12,25 \%$ \\
\hline cash ratio & 0,766953 & $-0,00533$ & 0,7670 & $5,11 \%$ \\
\hline total assets turnover & 0,432592 & $-0,09683$ & 0,4326 & $2,88 \%$ \\
\hline quick ratio & 0,254753 & $-0,00708$ & 0,2548 & $1,70 \%$ \\
\hline debt-to-equity ratio & $-0,25079$ & 1,027886 & 0,2508 & $1,67 \%$ \\
\hline equity multiplier & 0,250794 & $-0,27868$ & 0,2508 & $1,67 \%$ \\
\hline current ratio & 0,176994 & $-0,12442$ & 0,1770 & $1,18 \%$ \\
\hline enterprise value-to-revenue ratio & 0,144246 & 0 & 0,1442 & $0,96 \%$ \\
\hline general solvency & 0,113718 & $-0,13643$ & 0,1137 & $0,76 \%$ \\
\hline inventories turnover & 0,104497 & $-0,15348$ & 0,1045 & $0,70 \%$ \\
\hline Tobin's Q & 0,086437 & 0 & 0,0864 & $0,58 \%$ \\
\hline fixed assets turnover & 0,038767 & $-0,0785$ & 0,0388 & $0,26 \%$ \\
\hline $\mathrm{P} / \mathrm{B}$ ratio & 0,005172 & 0 & 0,0052 & $0,03 \%$ \\
\hline $\mathrm{P} / \mathrm{E}$ ratio & 0,00263 & $-0,02787$ & 0,0026 & $0,02 \%$ \\
\hline Total & & & 15 & $100 \%$ \\
\hline
\end{tabular}

Source: Authors calculations 
As shown in the table above, the variables highlighted with green (Return on Assets - ROA; Return on Equity - ROE; Solvency and Operating profit margin), are the ones selected for the Z-score function. These variables have recorded the highest 'a' coefficient values, and if we take into consideration the percentage as a secondary criterion for selection, these variables, represent almost $70 \%$ of the total. The variables highlighted with yellow (Long-term debt ratio and debt-to-equity ratio - financial leverage) are also included in the Z-score function to adjust the score with + or depending on how the company stands against the industry average. Also, the longterm debt ratio, came up third, after ROA and ROE which are the fundamental ratios for performance measurement.

\section{B. Z-score function}

As a result, the Z-score function based on the variables analyzed, and used in calculating the performance score for the companies in the luxury industry is the following:

\section{$Z=3,9837^{\star} X_{1}+2,4908^{\star} X_{2}+2,0136^{\star} X_{3}+1,8390^{\star} X_{4} \pm 2,0591^{\star} X_{5} \pm 0,2508^{\star} X_{6}+\sum b$}

Where:

$\mathrm{X}_{1}=$ Return on Assets

$\mathrm{X}_{2}=$ Return on Equity

$\mathrm{X}_{3}=$ Patrimonial solvency

$\mathrm{X}_{4}=$ Operating profit margin

$\mathrm{X}_{5}=$ Long-term debt ratio

$\mathrm{X}_{6}=$ Debt-to-equity ratio

By applying the Z-score function to the 10 companies analyzed in the period 2010-2019, the results obtained are presented in Table 3.

Table 3. Z-score function results, period 2010-2019

\begin{tabular}{|c|c|c|c|c|c|c|c|c|c|c|c|}
\hline 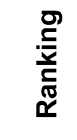 & 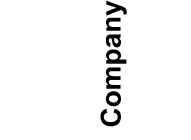 & 2019 & 2018 & 2017 & 2016 & 2015 & 2014 & 2013 & 2012 & 2011 & 2010 \\
\hline 1 & LVMH & 1,81 & 2,23 & 1,96 & 2,04 & 1,88 & 2,24 & 1,60 & 1,60 & 1,65 & 2,25 \\
\hline 2 & Estee Lauder & 2,40 & 1,82 & 2,00 & 2,30 & 2,59 & 2,53 & 2,83 & 2,63 & 2,42 & 1,69 \\
\hline 3 & Richemont & 2,12 & 1,67 & 1,51 & 1,79 & 1,76 & 1,96 & 2,02 & 1,98 & 1,84 & 1,43 \\
\hline 4 & Kering & 3,49 & 1,80 & 1,24 & 1,71 & 1,79 & 0,98 & 1,73 & 1,80 & 1,84 & 1,58 \\
\hline 5 & $\begin{array}{l}\text { Essilor } \\
\text { Luxottica }\end{array}$ & 1,38 & 1,42 & 2,14 & 1,98 & 1,72 & 2,42 & 2,05 & 2,11 & 2,10 & 2,11 \\
\hline 82 & Aeffe & 1,39 & 2,24 & 2,09 & 1,73 & 1,37 & 1,44 & 1,25 & 1,41 & 1,32 & 2,29 \\
\hline 87 & Tribhovandas & 1,66 & 1,82 & 1,73 & 1,51 & 1,78 & 2,09 & 2,47 & 2,76 & 2,37 & 1,84 \\
\hline 94 & Van de Velde & 2,10 & 2,32 & 2,93 & 3,02 & 3,22 & 1,51 & 2,40 & 2,24 & 2,83 & 2,93 \\
\hline 98 & Mulberry & 0,98 & 1,46 & 1,41 & 1,25 & 1,04 & 1,73 & 2,54 & 3,43 & 3,34 & 1,75 \\
\hline 100 & Trinity & 1,28 & 1,02 & 1,46 & 0,86 & 1,05 & 1,36 & 1,72 & 2,18 & 2,27 & 2,52 \\
\hline
\end{tabular}




\begin{tabular}{lllllllllll}
\hline MIN & 0,98 & 1,02 & 1,24 & 0,86 & 1,04 & 0,98 & 1,25 & 1,41 & 1,32 & 1,43 \\
MAX & 3,49 & 2,32 & 2,93 & 3,02 & 3,22 & 2,53 & 2,83 & 3,43 & 3,34 & 2,93 \\
\hline
\end{tabular}

Source: Authors calculations

According to the results of the Z-score function for the period analyzed:

- the scores highlighted with red represents the lowest values, and the majority were recorded by companies in the bottom ranking - Mulberry (2019, 2015); Trinity (2018, 2016); Aeffe (2013, 2012 and 2011). From the top-ranked companies, only Kering $(2017,2014)$ and Richemont (2010) recorded the lowest score values.

- the scores highlighted with green represents the highest values, also the majority recorded for the bottom-ranked companies like Van de Velde (2018, 2017, 2016 and 2010); Mulberry (2012, 2011). From the top-ranked companies, only 2 companies - Kering (2019) and Estee Lauder $(2014,2013)$ recorded the highest values.

Furthermore, by normalizing the Z-score function results, we have a better picture of the performance recorded by the companies in the luxury industry, see Table 4.

Table 4. Z-score function results with normalized data, period 2010-2019

\begin{tabular}{|c|c|c|c|c|c|c|c|c|c|c|c|}
\hline 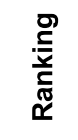 & 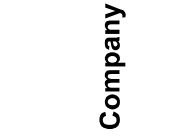 & 2019 & 2018 & 2017 & 2016 & 2015 & 2014 & 2013 & 2012 & 2011 & 2010 \\
\hline 1 & LVMH & 40 & 94 & 48 & 59 & 45 & 83 & 30 & 19 & 25 & 60 \\
\hline 2 & Estee Lauder & 61 & 65 & 50 & 70 & 74 & 100 & 100 & 65 & 59 & 26 \\
\hline 3 & Richemont & 51 & 55 & 25 & 48 & 39 & 67 & 54 & 35 & 33 & 10 \\
\hline 4 & Kering & 100 & 64 & 10 & 45 & 41 & 10 & 37 & 27 & 33 & 19 \\
\hline 5 & $\begin{array}{l}\text { Essilor } \\
\text { Luxottica }\end{array}$ & 24 & 38 & 58 & 57 & 38 & 94 & 55 & 41 & 45 & 51 \\
\hline 82 & Aeffe & 25 & 95 & 55 & 46 & 24 & 37 & 10 & 10 & 10 & 61 \\
\hline 87 & Tribhovandas & 35 & 66 & 36 & 37 & 40 & 74 & 79 & 70 & 57 & 35 \\
\hline 94 & Van de Velde & 50 & 100 & 100 & 100 & 100 & 41 & 76 & 47 & 77 & 100 \\
\hline 98 & Mulberry & 10 & 41 & 19 & 26 & 10 & 54 & 83 & 100 & 100 & 30 \\
\hline 100 & Trinity & 21 & 10 & 22 & 10 & 10 & 32 & 37 & 44 & 52 & 75 \\
\hline
\end{tabular}

Note: interval [10; 100], 10 - the weakest result and respectively 100 - the best result recorded by the company Source: Authors calculation

By looking at the results from the table above, after the results were normalized and we have an interval between 10 and 100, it can be noticed that in the lowest area, we can add Trinity (2015) because it records the same score as Mulberry in the same year. Also, the scores highlighted with orange shows us companies from the top and bottom ranking very close to the maximum performance score (100), e.g. LVMH $(2018,2014)$; Essilor Luxottica (2014); Aeffe (2018) and Mulberry (2013). 
As a result, the Z-score function in this way captures better the performance recorded by each company. If we take a closer look at the results, the top companies have fewer high results compared with the bottom companies, but the difference from one year to another is not that high. From the bottom companies, we can depict 2 underperformers (Trinity and Mulberry) and a top performer (Van de Velde).

The well-established companies like LVMH, Estee Lauder, Richemont, Kering, and Essilor Luxottica, record an above-average performance, without peaks in performance. Moreover, due to their experience, market share, brand value, brand recognition, and high YoY growth rate in terms of revenues, these companies have steady performance.

\section{Conclusions}

The Z-score function proved to be a suitable model for measuring the performance of the company. However, the model proposed based on ratio analysis in which the variables with the highest importance coefficient are selected, and then normalized to fit them into an interval brings some contributions through which we can describe better if a company is performing or underperforming. This aspect is important, especially when we make comparisons between large companies and small companies from the same industry, it helps us leveling the ground in terms of performance measurement, and we can compare 'apples to apples'.

The limitations of this research come from the fact that, in this paper, the ratio analysis does not include a ratio that measures the sustainability performance of the company. This would be a plus, and a closer representation of the performance as a whole since sustainability is an actual and a real concern. Furthermore, luxury fashion, a segment of the luxury industry is one of the highest polluters, and large corporations like LVMH, Kering, Richemont own brands in this segment. A model that captures the sustainability performance is a topic for further research and will provide valuable insights if it is considered in the performance measurement Z-score function and to the overall performance of the company.

\section{References}

Bloomenthal, A., (2020). Ratio analysis. Investopedia. [online] Available at: https://www.investopedia.com/terms/r/ratioanalysis.asp [Accessed on March 23 ${ }^{\text {rd }}, 2020$ ].

Brigham, E. F., \& Houston, J. F. (2019). Fundamentals of financial management. Ne/son Education.

Deloitte (2019). Global Powers of Luxury Goods 2019 - Bridging the gap between the old and the new. online] Available at: https://www2.deloitte.com/content/dam/Deloitte/ar/Documents/Consumer_and Industrial Pr oducts/Global-Powers-of-Luxury-Goods-abril-2019.pdf [Accessed on January 23 ${ }^{\text {rd }}, 2020$ ].

Refinitiv Eikon a Thomson Reuters' platform. (2020). Refinitiv Eikon. [online] Available at: https://eikon.thomsonreuters.com/index.html [Accessed on July $\left.3^{\text {rd }}, 2020\right]$.

Şerban, R. A., (2020) Performanța globală a companiei și factorii determinanți pentru crearea de valoare. Editura ULBS.

Șerban, R. A., \& Herciu, M. (2019). Performance Management Systems-Proposing and Testing a Conceptual Model. Studies in Business and Economics, 14(1), 231-244. 
Word Economic Forum. (2020). The Global Competitiveness index - Methdology. [online] Available at: https://reports.weforum.org/global-competitiveness-report-2018/chapter-3benchmarking-competitiveness-in-the-fourth-industrial-revolution-introducing-the-globalcompetitiveness-index-4-0/ [Accessed on August 2nd, 2020].

\section{Appendix}

\section{A. Liquidity ratios:}

- current ratio: $\frac{\text { Current assets }}{\text { Current liabilities }}$

- quick ratio: $\frac{\text { Current assets - Inventories }}{\text { Current liabilities }}$

- cash ratio: $\frac{\text { Cash and cash equivalents }}{\text { Current liabilities }}$

\section{B. Solvency ratios:}

$$
\text { Current liabilities }
$$

- general solvency: $\frac{\text { Total assets }}{\text { Total liabilities }}$

- $\quad$ patrimonial solvency: $\frac{\text { Shareholders equity }}{\text { (Shareholders equity + Long-term debts) }}$

\section{Profitability ratios:}

- return on assets (ROA): $\frac{\text { Net income }}{\text { Total assets }}$

- $\quad$ return on equity (ROE): $\frac{\text { Net income }}{\text { Shareholders equity }}$

- operating profit margin: $\frac{\text { Operating income }}{\text { Total revenues }}$

\section{Assets management ratios:}

- fixed assets turnover: $\frac{\text { Total revenues }}{\text { Fixed assets }}$

- inventories turnover: $\frac{\text { Total revenues }}{\text { Inventories }}$

- total assets turnover: $\frac{\text { Total revenues }}{\text { Total assets }}$

\section{E. Debt management ratios:}

- equity multiplier: $\frac{\text { Total assets }}{\text { Shareholders equity }}$

- debt-to-equity ratio (financial leverage): $\frac{\text { Total liabilities }}{\text { Shareholders equity }}$

- long-term debt ratio: $\frac{\text { Long-term debts }}{\text { (Shareholders equity + Long-term debts) }}$

\section{F. Market value ratios:}

- $\quad$ P/B ratio: $\frac{\text { Market value per share }}{\text { Book value per share }}$

- P/E ratio: $\frac{\text { Market value per share }}{\text { Earnings per share (EPS) }}$

- Tobin's Q ratio: $\frac{\text { Market value per share }}{\text { Total assets }}$

- EV/Revenues ratio: $\frac{\text { Enterprise value }}{\text { Total revenues }}$ 